\title{
Agglomeration, Transport, and Regional Development in Indonesia*
}

\author{
Uwe Deichmann, Kai Kaiser, Somik V. Lall, Zmarak Shalizi ${ }^{* *}$ \\ The World Bank
}

\begin{abstract}
How effective are public interventions in addressing significant regional disparities in formal manufacturing concentration in a developing economy? We examine the aggregate and sectoral geographic concentration of manufacturing industries for Indonesia, and estimate the impact of factors influencing location choice at the firm level. We distinguish between natural advantage, including infrastructure endowments, wage rates, and natural resource endowments, and production externalities, arising from the co-location of firms in the same or complementary industries. The methodology pays special attention to empirically distinguishing the impact of measured production externalities from unobserved local characteristics. Depending on the sector, we find that a mix of both forms of regional advantage explains the geographic distribution of firms. Based on the estimated location choice model, we illustrate the potential impacts of policy interventions on manufacturing distribution by simulating the effectiveness of transport improvements on relocation of firms. Our findings suggest that improvements in transport infrastructure may only have limited effects in attracting industry to secondary industrial centers outside of Java, especially in sectors already established in leading regions. The findings underscore the challenges for addressing the industrial fortunes of lagging regions, either through local decentralized policy interventions or national policies focused on infrastructure development.
\end{abstract}

\section{World Bank Policy Research Working Paper 3477, January 2005}

The Policy Research Working Paper Series disseminates the findings of work in progress to encourage the exchange of ideas about development issues. An objective of the series is to get the findings out quickly, even if the presentations are less than fully polished. The papers carry the names of the authors and should be cited accordingly. The findings, interpretations, and conclusions expressed in this paper are entirely those of the authors. They do not necessarily represent the view of the World Bank, its Executive Directors, or the countries they represent. Policy Research Working Papers are available online at http://econ.worldbank.org.

\footnotetext{
* This paper is part of a larger effort to understand the impact of spatial policy interventions on the regional distribution and performance of economic activities, particularly in lagging sub national regions. The research has been funded by a World Bank research program grant on "Urbanization and Quality of Life". We would like to thank the Indonesian Central Bureau of Statistics (BPS) for facilitating access to establishment level data, Alejandro Badel for excellent research assistance, and Ani Dasgupta and Neil McCulloch for useful discussions on regional development issues in Indonesia.

${ }^{* *}$ Authors names in alphabetical order. Author for correspondence: Somik V. Lall, Development Research Group, World Bank, 1818 H Street N.W., Washington DC 20433. Email: slall1@,worldbank.org, Fax: 1 2025223230
} 


\section{Agglomeration, Transport, and Regional Development in Indonesia}

\section{Introduction}

Formal manufacturing activity in Indonesia is highly concentrated. A simple Gini coefficient that measures the disparity of industrial employment distribution across districts (kota and kabupaten) in Indonesia measures 0.75 using combined data from the Economic Census and the Survey of Industry in 1996. ${ }^{1}$ About half of all manufacturing employment is located in just 15 districts, while 65 percent of districts, or almost 200 localities, share just 10 percent of the manufacturing workforce. The concentration of employment in individual industries exceeds that of employment overall. Two-thirds of the 31 main manufacturing sectors have a Gini coefficient of employment distribution of more than $0.9 .^{2}$

Employment distribution, of course, depends on population distribution, which is also quite uneven in a country of numerous islands. But with a Gini of 0.46 , population is significantly more dispersed across districts than manufacturing employment. Among the five sectors with the highest share of total manufacturing employment in the country, accounting for approximately half of the total, the textiles, garments and footwear sectors are highly concentrated. Ninety percent of all employment in the footwear sectors is concentrated in less than 5 percent of districts. The food processing and wood products sectors, which employ about 20 percent of total manufacturing employment, are the two least concentrated among the major industrial sectors in Indonesia. These sectors depend on the natural resource base and thus tend to locate close to widely dispersed agricultural land and forest resources. These patterns are confirmed in Figure 1, which contrasts employment distribution in the footwear and food products sectors. These are the most and least concentrated among the largest SIC-2 manufacturing sectors by employment. While there is considerable formal sector activity in the food sector in many parts of

\footnotetext{
${ }^{1}$ The Economic Census captures small firms, while the Survey of Industry canvases all firms with twenty or more employees. Coefficients using only firms in the 2001 Survey of Industry, which is used in the empirical section of this paper, are very similar.

${ }^{2}$ The 1996 manufacturing data use the 3-digit (Revision 2) ISIC codes. The 2001 Survey of Industry classifies main industrial sectors using the 2-digit codes (Revision 3).
} 
Sumatra, Kalimantan, and Sulawesi, the footwear sector is concentrated in the Jakarta and Surabaya metro areas in Java. Figures 2 and 3 show employment distribution in the remaining three of the five largest sectors in 1996- textiles, garments and wood products - and of total manufacturing employment.

Spatial concentration of economic activity occurs mainly because some regions have characteristics that attract more firms to be established there than in other regions. This implies that there are factors that are external to the microeconomic or firm-specific operations that boost productivity in one location compared to another (Venables 2003, Rosenthal and Strange 2003). This raises two important questions: the first is descriptive and concerns the nature of these factors. The second addresses normative issues about the underlying processes that lead to external economies. Of particular interest are determinants of productivity enhancing localized factors that can be influenced by public policy. In other words, what can policy makers do to encourage economic activity in lagging regions and influence the location decisions of private sector establishments if a more even distribution of economic opportunities is desired? And how do the costs and benefits of such efforts compare to alternative policy options?

In this paper, we examine the role of economic geography and related factors in explaining the inequalities in the distribution of industrial activity in Indonesia. We estimate a location choice model using establishment data from the Survey of Industry 2001 (SI), which includes all manufacturing firms with 20 or more employees. We assume that firms respond to a combination of productivity enhancing agglomeration economies and local characteristics that determine the "business environment" within a region. To identify and distinguish between different factors, we adapt the Bayer and Timmins (2003) equilibrium model of location choice to the question of industrial development. Based on the estimated location choice model, we illustrate the potential impacts of policy interventions on manufacturing distribution by simulating the effectiveness of transport improvements on relocation of firms out of the Jakarta Metropolitan area, which is by far the largest industrial agglomeration in the country. ${ }^{3}$

\footnotetext{
${ }^{3}$ Similar policy simulations can be carried out with other instruments such as labor regulations, industrial land supply, etc.
} 
This paper proceeds in five main sections. In Section 2, we review the literature on the sources of agglomeration economies and how they influence industry location decisions. Section 3 specifies the estimation framework and discusses identification issues for examining location decisions at the firm level. Sections 4 and 5 present results from the econometric analysis, and the policy simulations of the impact of transport improvements on industrialization in lagging regions. Section 6 briefly summarizes the contributions and implications of the findings.

\section{Agglomeration and Industry Location}

Significant spatial inequalities in economic activity as well as in welfare are not unique to Indonesia. ${ }^{4}$ Such patterns are largely the result of decisions by individual companies to locate in selected regions of a country. This creates employment, generates incomes and triggers spillovers into rural, services and supplying sectors. Understanding what motivates firm location decisions therefore helps explain the causes for spatial economic disparities.

We discuss two main groups of factors that influence location decisions by firms. The first includes those that are external to the firm. Some regions have a natural advantage that makes them relatively more attractive to different types of firms (Ellison and Glaeser, 1997 and 1999). This may include induced advantages such as good transport infrastructure that is the result of past public investment. These factors are central to the "New Economic Geography" models, where firms tend to locate in areas that have high demand for the good they produce facilitated through good transport infrastructure and thus market access (Krugman, 1991a; Krugman 1991b; Fujita and Krugman, 1995; and Fujita et al. 1999). Secondly, there are reasons for locating in a certain region that are more specific to the firm's production process and its interaction with suppliers, customers or competitors. These are production externalities where firms locate in proximity to other firms to benefit, for example, from knowledge or information transfers.

\footnotetext{
${ }^{4}$ Studies for large countries include China (Tianlun et al. 1996; Fujita and $\mathrm{Hu}, 2001$; Wen 2001; Zhang and Kanbur 2001), Brazil (Azzoni, 2001; Azzoni et al., 2003; Lall et al. 2004a), India (Besley and Burgess, 2002; Lall et al. 2004b; Lall and Chakravorty forthcoming), Mexico (Cikurel 2002; Deichmann, et al. 2004), and the United States (Fan and Casetti, 1994; Rey and Montouri, 1999).
} 
Over a longer time period, these factors may increase or decrease in importance. Initially, the conditions for the emergence of agglomeration economies might be due to natural endowment that historically encouraged early settlement and economic activity. These "first nature" geographies (Venables 2003; Burgess and Venables 2004) include sheltered harbors, natural resource endowments, access to inputs, proximity to markets and availability of basic infrastructure. The initial benefits can trigger a self-reinforcing process that leads to the emergence of urban-industrial agglomerations to a point where the initial advantage responsible for the growth of the center is no longer dominant. A well known example is New York City, which owed its early growth to its location near the mouth of the Erie Canal. Within 15 years of the canal's opening the city had surpassed Boston and Baltimore as the busiest port in America. Today, very little of New York's economic importance can be attributed to its port facilities.

In Indonesia, Java and particularly West Java's Jabotabek region has by far the highest concentration of manufacturing activity. ${ }^{5}$ Historically, Java's fertile volcanic soils supported high population densities, and by the $16^{\text {th }}$ century the port of Sunda Kelapa in today's Jakarta had established itself as an important trade hub. This in turn attracted the establishment of European trading posts and eventually the capital of the Republic of Indonesia. In the post-colonial period, Indonesia developed what some have called an economic system of "bureaucratic capitalism" where a high premium was on close access to members of the government. Large firms were often created by the state, by members of the government or military and their associates, or by ethnic Chinese businessmen. There was no prominent class of indigenous entrepreneurs, which might have created a more dispersed pattern of industrial development. These factors accelerated the agglomeration of economic activity near the seat of power in a highly centralized political system and resulted in the rapid growth of the manufacturing sector in the Jakarta region in the 1980s and early 1990s. By 1991 the manufacturing share of GDP in Indonesia exceeded that of agriculture and most of that was generated in western Java. Additional centers of manufacturing include Surabaya in Eastern Java - originally a Dutch center of naval industry - and Bandung, at the center of the highland plantation

\footnotetext{
${ }^{5}$ Jabotabek is the metropolitan area consisting of Jakarta, Bogor, Tangerang, and Bekasi.
} 
economy and recently a center of textile manufacturing. Two smaller manufacturing centers, Medan in Sumatra and Ujung Pandang (Makassar) in southern Sulawesi, also owe their existence largely to their role as regional trading posts.

These processes of agglomeration are supported by public infrastructure, especially in the transport sector. Krugman (1991b) shows that manufacturing firms tend to locate in regions with larger market demand to realize scale economies and minimize transportation costs. If transport costs are very high, then activity is dispersed. In the extreme case, under autarky, every location must produce everything locally. If transport costs are negligible, firms may be randomly distributed as proximity to markets or suppliers will not matter. Agglomeration occurs at intermediate transport costs especially when the spatial mobility of labor is low (Fujita and Thisse 1996). Low transport costs allow larger scale production, which in turn creates investment activities in other industries. By increasing demand for each other's products this process of simultaneous investment raises profitability thus allowing all firms to realize pecuniary externality benefits (Murphy et al. 1989).

In addition to the pure pecuniary benefits from reducing transport costs, availability of good infrastructure increases the potential for input diversity, a larger labor pool, as well as the probability of technology diffusion through interaction and knowledge spillovers between firms. Thus, improved accessibility has the effect of reducing geographic barriers to interaction, which increases specialized labor supply and facilitates information exchange, technology diffusion and other beneficial spillovers that have a self-reinforcing effect (see Henderson et. al 2001, Lall et. al 2004; McCann 1998, for a detailed discussion on this issue).

Other region specific characteristics that influence industry location decisions include local labor costs and administrative policies that support or obstruct business development such as regulation, taxation and amenity provision. A range of registrations, operating licenses (e.g., zoning permits or environmental impact assessments), minimum wage and employment regulations, and taxation can influence the cost of doing business in a particular location. This also includes the prevalence of 
informal payments, outright corruption, or "predatory" taxation. Firms in Indonesia must interact with the bureaucracy at the national (Jakarta) and regional level (i.e., provincial and local governments). ${ }^{6}$ While the central bureaucracy may not formally differentiate in its licensing processes across regions, transaction costs may increase for firms located further from the central bureaucracy (e.g., owing to delays and uncertainty stemming from absence of face to face contact). At the regional level, certain provincial or local bureaucracies may simply be more prone to corruption and/or predatory taxation. At the same time, accountability mechanisms (e.g., voice or exit options on the part of firms) may not be sufficient to act as a disciplining device on local bureaucracies. Since Indonesia's decentralization in 2001, businesses have primarily complained about nuisance or even predatory taxation on the part of local governments.

Production externalities, in contrast, relate to dynamics that directly affect the firm's microeconomic decision making. Most fundamentally, clusters of firms that are predominantly in the same sector take advantage of localization economies. They include sharing of sector specific inputs, skilled labor and knowledge, intra-industry linkages, and opportunities for efficient subcontracting. Marshall-Arrow-Romer ${ }^{7}$ externalities suggest that cost-saving externalities are maximized when a local industry is specialized. These models predict that these externalities predominantly occur within the same industry. Therefore, if an industry is subject to such externalities, firms are likely to locate in a few regions where other producers of that industry are already clustered.

At the next level, intra-industry externality effects may be complemented by inter-industry linkages in the form of buyer-supplier relationships. Empirically, the distinction between own-industry versus cross-industry linkages is of course dependent on the level of sectoral aggregation. At the two-digit industry code level, many activities are considered internal to the sector that would be classified as cross-sectoral using a three-digit classification. So at high levels of sectoral aggregation, an input-output table, which summarizes buyer-supplier linkages between sectors, will show flows of goods as

\footnotetext{
${ }^{6}$ Formally modeling the net cost of dealing with the bureaucracy is challenging, especially as these may be endogenous to a firm within a given location. For example, individual businesses may pay lower taxes through informal payments, although rent extraction by individual bureaucrats may also be reflected in the quality of locally provided infrastructure services.

${ }^{7}$ Following Marshall (1890), Arrow (1962), and Romer (1986).
} 
diagonal table elements, which would be off-diagonal inter-industry transactions in a less aggregated sectoral classification. For an industry heavily dependent on intermediate goods and services as inputs to production, access to suppliers lowers transaction costs and increases profitability. Inter-industry linkages can also serve as a channel for vital information transfers. Firms that are linked through stable buyer-supplier chains exchange ideas on how to improve the quality of their products or on how to realize cost savings.

Finally, a larger overall size of the urban agglomeration and its more diverse industry mix is thought to provide external benefits beyond those realized within a single sector or a tight buyer-supplier network (Henderson 2003). These benefits are typically called urbanization economies. Larger cities have a greater diversity of firms. This allows greater specialization since it enables small, innovative firms to access a larger pool of potential buyers and complementary services that cannot be provided in-house. Larger cities also provide a larger home market for end products, make it easier to attract skilled employees who are attracted by urban amenities not available in smaller towns, and support a large number of complementary service providers such as financial and legal advisers, advertising and real estate services. Manufacturing firms will also require complementary services such as legal, financial and other advisory services. These are likely to be available in larger, more diverse urban areas.

Localization economies, I-O linkages and urbanization economies are not mutually exclusive. They may occur individually or in combination. The degree to which these factors are present provides a characterization of the economic base of a region. Table 1 gives some examples.

\section{Empirical specification, identification and data sources}

\section{Firm decision model}

The objective of this paper is to investigate what factors influence the location decisions of manufacturing firms in Indonesia. In this section, we provide an estimation framework, where individual firms compare potential profitability across all kabupaten or districts in Indonesia. We assume that a firm evaluates potential profits at alternative 
locations at each time period, and would consider relocation if profits in another place exceeded its profits at the current location. By viewing past location decisions as being under constant review by firms, this framework allows us to investigate what location benefits are embedded in the firm's current production technology. In reality, firm location is of course more "sticky" than our model suggests. Firms have to consider sunk investment in production capacity, limited mobility of their workforce and cost of moving.

On the other hand, Henderson et al. (1996) show that existing firms do move. For example, many firms moved out of Jakarta to the peripheral areas of the Greater Jakarta metropolitan region in the mid 1980s. These moves were facilitated by the construction of toll-ring roads around the city. Firms retained many of the agglomeration benefits of being in the metropolitan region, but reduced congestion costs (e.g., land rents and transport costs). This enabled firms to benefit from lower land and labor costs in the periphery, which exceeded the increased costs of transport serving the same market. Aggregate transport costs per unit of sales revenue also dropped as a larger market could be accessed through a better network.

The units of observation in our analysis are all registered Indonesian manufacturing firms with 20 or more employees, using data from the Survey of Industry 2001 (SI). Since corresponding economic censuses are only conducted each decade (including 1996), we did not include small firms in the analysis. Small firms will usually be more informal and locally rooted family-run enterprises that are unlikely to be as systematic in their location choice as our model assumes or as mobile in response to changing locational incentives. We therefore believe that limiting the analysis to larger firms is justifiable. The data set includes more than 21,000 firms employing about 4.4 million workers. Among the largest sectors by number of firms and employees are the food, textile and wearing apparel industries. Table 2 provides the sectoral disaggregation at the two-digit level, as well as the number of firms and employees. ${ }^{8}$

\footnotetext{
${ }^{8}$ We combined smaller sectors $30 \& 33$ and $31 \& 32$, and leave out sector 37 (Recycling) from the analysis.
} 
The underlying location decision model for each firm determines profits as a function of observable location specific characteristics (i.e., natural advantages), market access, agglomeration economies, and a set of unobserved local attributes of the district. In the model profits $\pi$ earned by firm $i$, in industry $k$, which chooses to locate in region $j$ are: ${ }^{9}$

$$
\pi_{i, j, k}=f\left(\sigma_{j, k}, \Lambda_{j, k}, B S_{j}, M A_{j}, W_{j}, R_{j}, X_{j, k}, \xi_{j, k}, \eta_{i, j, k} ; \bar{\beta}_{k}\right) .
$$

Agglomeration effects that provide production externalities are measured by a number of variables: $\sigma_{j, k}$ are localization economies, represented by the share of firms of type $k$ found in location $j ; \Lambda_{j, k}$ are inter-industry trading relations measured by the strength of buyer-supplier linkages; and $B S_{\mathrm{j}}$ are urbanization economies in location $j{ }^{10}$

$M A_{j}$ summarizes regional market access attributes, measured by quality and availability of transport infrastructure. Other regional characteristics include $W_{j}$, a vector of factor input price variables in location $j$ (e.g., non agricultural wages), $R_{j}$ measuring various aspects of government involvement, such as the supply of serviced industrial land on the one hand and engaging in predatory taxation on the other, and $X_{j, k}$ which captures other observed sources of natural advantage in $j$ that are specific to firms of industry $k$, such as proximity to sources of raw materials.

Next, $\xi_{j, k}$ measures unobserved characteristics of the kabupaten which can affect the firm's profits. These factors are considered by each firm at the time it is making its location decision, but are not captured in the data. Presence of these unobservable local attributes of a location's natural advantage complicates the estimation procedure, particularly in identifying the contribution of production externalities to the location decisions of firms. Ellison and Glaeser (1997) point out that the effects of unobservable sources of "natural advantage" (i.e., positive values of $\xi_{j, k}$ ) will not be separately

\footnotetext{
${ }^{9}$ This model is an adaptation of the Bayer and Timmis (2003) equilibrium model of location choice to the problem of industrial development.

${ }^{10}$ We use the share of region $j$ 's employment in business services such as finance, insurance, and real estate, to measure urbanization economies. As these are complementary to manufacturing activity and typically increase with city size, these should be a good indicator of the benefits from urbanization economies.
} 
identified from those of production externalities between firms that arise simply from firms locating near one another. Simply including the number of firms or employment in a particular industry, which is a commonly used indicator in empirical studies evaluating localization economies, will not allow us to distinguish whether firms are attracted by a common unobservable, whether they derive benefits from being located in close proximity to one another, or whether it is some combination of the two. As it is impossible to get data on all the factors relevant to a firm's location decision, it is essential to find an instrument for own industry concentration that is not correlated with the unobservable sources of natural advantage, $\xi_{j, k}$.

Finally, $\eta_{i, j, k}$ is an idiosyncratic unobserved component of profitability in location $j$ for firm $i$ of industry $k$, and $\bar{\beta}_{k}$ is the industry specific parameter estimate for each of these determinants of profitability.

\section{Data}

Table 3 lists the variables used in our empirical estimation of industry location as well as their definition, sources and summary statistics. Localization economies are measured as the proportion of sector $k$ firms in location $j$ as a share of all of sector $k$ 's firms in the country. The higher this value, the more we expect to find intra-industry concentration benefits in the region.

Our indicator for linkages between buyers and suppliers is based on the Indonesian input-output table for 2000. For each sector we compute the presence of industry specific backward linkages in each district. Backward linkages are usually measured as technical coefficients from a national industry by industry transactions table. Technical coefficients are defined as the amount that the purchasing industry buys from the selling industry divided by the sum of all purchasing industry sales. They represent the value of intermediate purchases from the selling sector required to produce a dollar of the purchasing industry's output. It is thus a measure of the degree of the purchasing industry's dependence on other industries for inputs to production. 
We measure the firm's dependence on backward linkages as the sum of its industry's backward linkages with all other relevant sectors. Since we only have a national input-output table, we need to assume that technology across a sector's firms is fixed. Sectors however, are not equally represented in each district. We therefore modify the national measure of backward linkages by weighting the technical coefficients by the region's location quotient for the selling industry.

To illustrate, a matrix of regionally weighted backward linkages is defined as

$$
\Lambda_{(j x k)}=\underset{(j x k)(k x k)}{\mathbf{\Omega}}
$$

where $\mathrm{L}$ is a region by industry matrix of location quotients for selling sectors. Each element of $\mathrm{L}$ is calculated as

$$
L_{j k}=\frac{e_{j k} \sum_{j} \sum_{k} e_{j k}}{\sum_{j} e_{j k} \sum e_{j k}},
$$

where $e_{j k}$ is employment in region $j$ and industry $k . \Omega$ is a national direct requirements matrix of technical coefficients with purchasing industries as columns and supplying sectors as rows. Each column vector of $\Lambda$ is a composite measure of the $k^{\text {th }}$ industry's backward linkages for regions $j$. Therefore, a firm in region $j$ and industry $k$ has a measure of backward linkages $\Lambda_{j k}$.

The availability of business services sheds light on whether urbanization economies influence industry location decisions across sectors. No detailed information on the service sector firm composition by district is available. Instead we use a proxy based on employment composition derived from the annual Indonesian socio-economic survey household survey (SUSENAS), as each district's share of employment in sectors that provide business services. ${ }^{11}$

\footnotetext{
${ }^{11}$ Sectors representing business services are based on the ISIC (revision 3) classification of economic activities, and includes financial intermediation, real estate, and business activities (ISIC sectors 651-702, and 721-749). In particular, business activities in the ISIC classification include legal, accounting, bookkeeping and auditing activities; tax consultancy; market research and public opinion polling; business and
} 
Market access is measured in two different ways. The first is a simple measure of road density in each district. We derived this indicator by computing the length of all road segments in each kabupaten using a geographically referenced data set of major roads from the Survey of Indonesia augmented by the road network from the Digital Chart of the World (ESRI 1993). To ensure comparability with national road statistics we then adjusted the total road length in each district so that the provincial totals match the figures published by the national statistical office (BPS 1997; the latest year for which these figures are available).

While this indicator measures the ease by which goods and people can move locally, the second indicator measures the ease by which goods can be moved to export hubs. This variable - travel time to the nearest international port - is calculated as the average travel time on the road network from all points in a district to the nearest international port able to handle containers.

Indonesian manufacturing is specialized in low technology standardized products, which are typically not involved in significant product or process innovations. As these industries have limited need for specialized workers, inter-regional variations in labor costs for low skilled workers are likely to be an important component of the location decisions made by entrepreneurs. For the analysis in this paper, we use non-agricultural hourly wages as the indicator of labor costs. We obtained wage rates from the 2001 round of the SUSENAS, as the district average of head of household wages for workers in salaried jobs. These are nominal wages, since firms will consider the total wage bill regardless of cost of living differentials across regions. There is considerable inter regional variation in wages across districts, as shown in Figure 4.

To proxy for negative government action, we use an indicator of excessive or predatory taxation by local governments. Local legislatures in Indonesia can issue regional bylaws and regulations (PERDAs), including those concerning taxes and levies as per Law 34/2000. In addition to a specified tax and charges base (e.g., street lighting taxes), local governments can pursue revenue sources as long as they do not contradict 
the national tax base (e.g., they may not impact inter-regional commerce). This open rather than closed list of taxation has raised concerns among the business community about the proliferation of nuisance or even predatory taxation. To counter the potential of abuse, local governments must report all new PERDAs to the Ministry of Home Affairs. PERDAs associated with taxation or user charges are then reviewed in an interministerial working group, with participation of the Ministry of Finance. For the purposes of our analysis, we used a dummy variable of one if the central government found at least one PERDA in a district that contravened the open list principle, i.e., reflecting poor consultation, nuisance or predatory revenue behavior on the part of local government increasing uncertainty and the local cost of doing business.

As a measure of service provision by governments that may influence industry location decisions, we examine the supply of serviced industrial land in each district, which is derived from the PODES village level survey (BPS 2001). In many cases, local governments promote industrial estates, which can be either publicly or privately operated, and provide basic infrastructure, serviced land, and a host of other supporting facilities, including licensing and security.

Industrial sectors that depend on naturally produced raw materials will consider proximity to the sources of those inputs as an advantage. Examples are food processing that is tied to agriculture and wood products dependent on logging activities. We create indicators of the regional importance of cropland and forests from a spatial database of land cover (JRC 2003). They are defined as the percent of district area covered by cropland and various types of forests, respectively.

\section{Identification strategy}

To address the identification issues described earlier in the paper, we modify a strategy for constructing instruments for own industry concentration $\left(\sigma_{j, k}\right)$ proposed by Bayer and Timmins (2003). The basic idea is to use predicted type-specific industry shares based only on exogenous local attributes. However, we do not have adequate variation in exogenous local attributes that vary significantly by industry sector $k$. Instead we employ historical values of industry concentration (in this case industry shares). In 
the presence of path dependence, these will be good predictors of current industry shares, but will not be correlated with current unobservable sources of natural advantage. We compute industry shares using the 1975 Survey of Industry, after reconciling differences in sectoral definitions ${ }^{12}$ and district boundaries. 1975 is the earliest year for which district level industry data are available and represents the status prior to the beginning of significant growth in modern manufacturing in Indonesia (Hill 1990).

As in the case of industry concentration, we also need to address the endogeneity of business services, since the availability of such services in a region may be a consequence of the earlier location decisions of manufacturing firms. Their presence may also be driven by location specific unobservables, and we face the possibility of attributing the impact of these unobservable factors to the impact of business services. To correct for this problem, we instrument employment in business services with the share of villages in each district with a vocational training high school. This instrument is a good predictor of a district's production of skilled business service employees.

We choose the following functional form for this profit function:

$$
\begin{aligned}
& \pi_{i, j, k}=\beta_{0, k}+\beta_{\sigma, k} \sigma_{j, k}+\beta_{\Lambda, k} \Lambda_{j, k}+\beta_{B S, k} B S_{j}+ \\
& \beta_{M A, k} M A_{j}+\beta_{W, k} W_{j}+\beta_{R, k} R_{j}+\beta_{X, k} X_{j, k}+\xi_{j, k}+\eta_{i, j, k}
\end{aligned}
$$

Given the hundreds of districts in Indonesia where firms can choose to locate, we assume a Type-II extreme value distribution for the idiosyncratic error, $\eta_{i, j, k}$. The probability that any firm of type $k$ will choose to locate in kabupaten $j$ is therefore (see McFadden, 1973):

$$
P\left(\pi_{i, j, k} \geq \pi_{i, l, k} \forall l \neq j\right)=\frac{e^{\beta_{0, k}+\beta_{M A, k} M A_{j}+\beta_{\sigma, k} \sigma_{j, k}+\beta_{\Lambda, k} \Lambda_{j, k}+\beta_{B S, k} B S_{j}+\beta_{W, k} W_{j}+\beta_{R, k} R_{j}+\beta_{X, k} X_{j, k}+\xi_{j, k}}}{\sum_{m=1}^{J} e^{\beta_{0, k}+\beta_{M A, k} M A_{m}+\beta_{\sigma, k} \sigma_{m, k}+\beta_{\Lambda, k} \Lambda_{m, k}+\beta_{B S, k} B S_{m}+\beta_{W, k} W_{m}+\beta_{R, k} R_{m}+\beta_{X, k} X_{m, k}+\xi_{m, k}}}
$$

\footnotetext{
${ }^{12}$ Indonesia moved from the ISIC Revision 1 to ISIC Revision 3 industry classification between 1975 and 2001.
} 
If none of the components of the profit function differ at the level of the individual firm $i$, we re-write this expression:

$$
\pi_{i, j, k}=\theta_{j, k}+\eta_{i, j, k}
$$

which implies that the only differences between firms comes from the idiosyncratic unobservable, $\eta_{i, j, k}$, We then construct a set of industry-specific likelihood functions based on equations (5) and (6), with which we recover estimates of the full vector $\bar{\theta}_{j, k}, k=1,2, \ldots, K$. In the second stage, we take the estimated value of the choice specific constant, $\hat{\theta}_{j, k}$, and estimate the following regression:

$$
\hat{\theta}_{j, k}=\beta_{0, k}+\beta_{M A, k} M A_{j}+\beta_{\sigma, k} \sigma_{j, k}+\beta_{\gamma, k} \gamma_{j, k}+\beta_{B S, k} B S_{j}+\beta_{W, k} W_{j}+\beta_{R, k} R_{j}+\beta_{X, k} X_{j, k}+\xi_{j, k}
$$

As discussed earlier in this section, estimating (7) using OLS will provide biased effects for own industry shares and business services. To correct for the endogeneity of these variables, we estimate (7) using IV methods for each industry sector $(k)$ under consideration. $^{13}$

The estimation is carried out in two parts. First, we recover a set of sector specific regional fixed effects from estimating a conditional logit model (equation 6). ${ }^{14}$ In the second part, we estimate equation (7), where we examine the determinants of the estimated fixed effects using instrumental variables.

\footnotetext{
${ }^{13}$ This is not a negligible issue as we find that OLS estimates provide considerable upward bias on the impacts of own industry concentration.

14 The estimated fixed effects are not reported here, but are available on request.
} 


\section{Location decisions of firms - Why do we see concentration?}

The results from estimating equation 7 are presented in Table 4 and discussed as follows: (a) Agglomeration economies, (b) Market access, and (c) Observed natural advantages.

\section{Productivity Effects -- Agglomeration Economies}

We first discuss the effects of own industry concentration, or localization economies. These are measured as each kabupaten's share of firms in a given industry. The estimated parameters are positive for all sectors and statistically significant (at the 10 percent level) for nine of the 15 industries. This suggests that, at this level of industrial and geographic aggregation, own-industry concentration or localization economies have a considerable impact on location decisions of firms in a majority of sectors. An example is the wood products industry, which employs over 400,000 people in the formal sector. The results for wood products concentration suggest that one standard deviation increase from the mean in a district's share of wood products firms increases (the log of) regional attractiveness by 10.5 percent. In comparison to wood products, which employs relatively low technology, the results for the office, accounting, and computing machinery industry - at the upper end of the local technology spectrum - imply that a one standard deviation increase from the mean of this sector's firms increases regional attractiveness by about 120 percent. This means that own industry concentration is considerably more important in the location decisions of firms in the office and computing sector relative to the wood products sector.

The findings for backward linkages (suppliers) show that for most industry sectors, proximity to buyers and suppliers enhances potential profits, and therefore influence location decisions at the firm level. While the estimated coefficients are positive for nine sectors, they are statistically significant for five sectors - food, wearing apparel, chemicals, rubber, and non metallic mineral products. The estimated coefficient of 0.49 for the food and beverage sector suggests that a one standard deviation increase from the mean in a district's representation of industry specific intermediate suppliers increases the (log of) regional attractiveness by around 6 percent. Similarly, in the 
wearing apparel sector, the estimated coefficient of 0.65 implies that a one standard deviation increase in backward linkages improves the (log of) regional attractiveness by 16 percent.

Our estimates for urbanization economies, measured by the share of district employment in business services indicate that these are significant in influencing industry location in only a handful of sectors - wearing apparel, leather, chemicals, and rubber and plastics products. The coefficients for business services shown in Table 4 are corrected for the endogeneity of business services by using the share of villages within a district with technical training facilities as instruments. The estimated coefficient of 15.67 means that a one standard deviation increase from the mean in the region's share of employment in business services increases (log of) regional attractiveness by 12.3 percent. Similarly, the coefficient of 26.99 translates into a 17.1 percent gain for a one standard deviation increase in the rubber and plastics products sector. These estimates suggest that urbanization economies, at least measured through business services influence location decisions in only a few sectors.

\section{Output Markets:}

External Markets - Locating in a region with good access to markets is likely to increase demand for the firm's products. As both regional attractiveness (the fixed effects) and port distance are in logs, the estimated coefficients can be interpreted as elasticities. We find that port distance significantly influences location decisions in six sectors. It is highly significant in the apparel, wood and paper products sectors, all of which have strong export orientation. For example, in wearing apparel, the coefficient of -0.07 means that a 10 percent reduction in distance to the nearest international port will be associated with an approximately 0.7 percent increase in regional attractiveness or potential profitability. On the other hand, for example in wood and paper products, the coefficient of -0.08 means that a 10 percent increase in distance to the nearest international port will be associated with an approximately 0.8 percent decrease in regional attractiveness. 
Internal Markets - As with travel time to ports, road density is measured in logs and the estimated coefficients are elasticities of road density with respect to regional attractiveness. The estimated coefficients for road density are positive and statistically significant for seven industry sectors, with large elasticities in the textiles, wearing apparel and furniture sectors. The elasticity of 0.56 in textiles means that a 10 percent increase in road density will be associated with an approximately 5.6 percent increase in regional attractiveness. Similarly, for the furniture industry, the elasticity of 0.33 implies that a doubling of road density will increase regional attractiveness by 33 percent.

\section{Observed regional characteristics, factor markets and natural advantages}

Labor : Firms in Indonesia appear to be attracted to areas with lower wages. For nine of the 15 sectors, the wage indicator is consistently negative and significant. While wages are an important part of location decisions of firms engaged in activities at the lower end of the technology spectrum, such as food products, wearing apparel, leather products, and furniture, these do not matter in sectors such as office and computing machinery and electrical and electronics products. The estimated coefficients are elasticities, and the value of -0.52 in wearing apparel means that a 10 percent increase in district wages reduces a district's attractiveness by 5.2 percent. Similarly, the coefficient of -0.64 for furniture means that a 10 percent increase in local wages reduces the district's attractiveness by 6.4 percent.

Capital / Land: Among the other inputs in a firms' production function, the land variable measures the amount of developed industrial land that is available in each district. This variable is only significant in three industry sectors - food products, rubber and plastic, and furniture. The estimated coefficients are elasticities. For example, the coefficient of 0.06 for food products means that a 10 percent increase in the availability of industrial land improves the district's attractiveness by 0.64 percent for firms in this sector.

Non welfare improving regulations: Our measure of predatory local government taxation is an indicator variable that shows whether the Ministry of Home Affairs rejected a PERDA that was introduced by a kabupaten. It intends to capture the impact of the cost 
of regulatory compliance on location decision of firms. Due to data limitations, we use a dummy variable in the analysis, which does not capture many aspect of local government taxation or regulations. A negative coefficient suggests that firms are reluctant to locate in areas which engage in predatory or nuisance taxation. We find that while the estimated coefficients are negative for nine industry sectors, these are statistically significant in only two sectors - tobacco and wood products.

Natural Resources: For industrial sectors that depend on the natural resource base, especially food processing that is tied to agriculture and wood products dependent on logging activities, we may presume that they would locate near the sources of their raw materials. The crop land indicator is the percent of district area covered by crop land categories, and, correspondingly, the forest cover variable is the sum of the shares of land covered by various types of forests. We find that the forest cover variable is positive and significant in the wood products sector. The share of crop land is positive and significant in the location decisions of rubber and plastics products companies - most likely a spurious correlation.

The low importance of these variables could be due to a number of reasons. The variable may be poorly measured since the data are derived from relatively coarse one $\mathrm{km}$ resolution data sets. Or the actual land allocated, for instance, to the production of agricultural products for further processing may be relatively insignificant compared to crop land allocated to subsistence agriculture or cultivation for direct sale. Another explanation may be that firms prefer to ship the raw materials to processing centers that are located in areas that offer other advantages. For the food sector we have already discussed that the presence of intermediate suppliers may reflect the preferences of food processing firms to locate in more diverse areas. 


\section{Simulations}

The previous section has highlighted the importance of production externalities for firm location choices. In equilibrium, each firm must make its optimal location decision taking the location decision of all other firms as given. ${ }^{15}$ The decision of a firm affects the decision of other firms via agglomeration and congestion effects. The relevant issue in terms of lagging regional development is the type and scale of improvements in regional characteristics that are needed to offset benefits from locating in existing agglomerations, and induce firms to move towards peripheral locations. Improvements in regional characteristics can be brought about by various instruments. These include improving the investment climate by reducing sub optimal and predatory taxation; investments in social infrastructure such as health and education; as well as investments in physical infrastructure. In this section, we use the estimates from the location choice model to illustrate the potential impacts of transport improvements on relocation of firms, particularly into the lagging eastern part of the country.

We simulate an increase of road density for the following regions:

(a) Greater Jakarta Metropolitan area (100 Km belt around DKI Jakarta)

(b) Greater Jakarta Metropolitan area (excluding DKI Jakarta)

(c) Municipalities in East Java

(d) All districts in East Java

(e) Municipalities in East Kalimantan and South Sulawesi (Eastern Indonesia)

(f) All districts in East Kalimantan and South Sulawesi (Eastern Indonesia)

We selected East Kalimantan and South Sulawesi in Eastern Indonesia, as these can be considered as secondary industrial centers outside of Java. In these simulations, we provide a scenario where road densities are increased to 2,500 $\mathrm{km}$ road length per $1,000 \mathrm{~km}^{2}$ of area. We use this scenario as there are currently considerable variations in road densities across these regions, and improving densities to 2,500 km per $1,000 \mathrm{~km}^{2}$ would close the gap between districts in Eastern Indonesia and the Jakarta Metro Area. In

\footnotetext{
${ }^{15}$ Along with exogenous location specific characteristics.
} 
essence, we ask the question: what would happen to distribution of manufacturing if road densities in peripheral Eastern Indonesia were upgraded to a level similar to the country's major agglomeration (Jakarta)? Would this stimulate large-scale migration of firms to peripheral areas? Or are agglomeration forces and other amenities strong enough to limit the scale of firm migration?

Current road densities are summarized in Table 5. Existing road densities are considerably different across regions, which means that the cost of improvements is also likely to vary significantly. It is clear that current road densities in Eastern Kalimantan and Southern Sulawesi would have to be increased by approximately 500 percent to reach the target of 2,500 km per 1,000 $\mathrm{km}^{2}$. In comparison, road densities for all East Java would have to be increased by 250 percent. Even assuming road construction to cost the same in central areas as in remote areas, this means that it would cost at least twice as much to bring parity between areas in East Java and those in East Kalimantan and South Sulawesi. The question of interest in this case is the impact of these large scale transport improvements on industry relocation - i.e. what is the net gain in terms of new economic activity in response to these large scale expenditure programs?

As the impacts of transport improvements are likely to vary by sector, we chose industry sectors based on sensitivity (based on estimates from the location choice model) to transport improvement and agglomeration economies (Table 6). Industries such as garments, which are highly sensitive to transport and show low agglomeration economies, are likely to show some firm movement in response to transport improvements in outlying areas. In comparison, industries such as office computing that have low sensitivity to transport and exhibit high agglomeration economies are unlikely to move in response to transport improvements. Table 6 presents the sectors we use for the simulations, along with their transport sensitivities. The transport rankings in Table 6 are based on a rank ordering of elasticities of road densities derived from estimating the location choice model.

The impacts of the simulated transport improvements are presented in Figure 5. The sectors have been organized by sensitivity to transport improvements - high, 
moderate and low. Before summarizing the results, we first describe the mechanics behind the simulations. Improvements in transport will enhance regional attractiveness, which increases profits for firms that are already located in the region. If, as a result of transport improvements, potential profits in this region become higher than potential profits in other regions, firms will migrate to gain from these untapped opportunities. In principle, this process should continue until there is convergence in the sense that congestion costs (such as increases in land and labor costs) are high enough to offset net benefits from industry relocation and the system gets back into equilibrium. However, we limit our simulation exercise to one iteration of this process, as we cannot account for other factors, such as the effects of additional firms moving in on land prices and wages, or the labor supply response from other locations in response to increasing firm densities.

In Figure 5, there are two bars for each region. The bar on the left shows the baseline number of firms, and the bar on the right shows the number of firms after introducing transport improvements in that region. These figures do not show the impact of improving transport densities on firm densities in other regions - e.g., what happens to the number of firms in the Jakarta Metro area in response to transport improvements in East Java? ${ }^{16}$ Figure 5a shows the regional impacts for the garments and rubber and plastic sectors, which are highly sensitive to transport. We find that there is some relocation of firms to peripheral areas after transport improvements. However, where agglomeration economies are strong, as in the case of rubber and plastics, the scope of industry relocation to peripheral locations (East Kalimantan and South Sulawesi) is much lower than when agglomeration economies are weak.

Figure $5 \mathrm{~b}$ shows regional impacts for wood products and rubber and plastics sectors. These sectors are moderately sensitive to transport and are the least concentrated among the major industrial sectors in Indonesia. Both sectors exhibit limited returns to scale, thus having a larger extent of regional representation. In both cases, transport improvements have small impacts on industry relocation, especially to the peripheral areas, partly because these sectors are already well distributed, and serve local markets.

\footnotetext{
16 These estimates can be provided on request.
} 
Figure 5c shows the impacts of transport improvements for leather products and office computing sectors - both these sectors are highly concentrated and show low sensitivity to transport. We find that road transport improvements are unlikely to influence profitability, and thus industry location decisions in these industries.

Our simulations show that there are very small impacts of large scale transport improvements in terms of industry relocation to Indonesia's lagging eastern region. Even for sectors with high transport sensitivity, it is not clear if the scale of relocating economic activity corresponds to the scale of investment. For instance, is it fiscally sustainable to engage in large scale transport improvement programs to attract a handful of firms? Or might it be more prudent to develop policies that provide people with the skills that allow them to be absorbed in existing dynamic labor markets in regions with higher agglomeration levels?

\section{Conclusions}

Lagging region development is an important component of the Indonesian public policy debate. Historically, Indonesia has had some explicit regional development policies. These have been motivated by economic and social disparities across the archipelago, and concerns about specific regions such as Eastern Indonesia. Although Eastern Indonesia contains several relatively affluent and natural resource endowed provinces, its development lags behind that of western Indonesia (Java, Bali, and Sumatra), mainly due to low population density, the remoteness of some communities, inadequate infrastructure, and high transport costs.

Indonesian regional policies have resorted to a range of instruments. The central government has distributed investment grants focused on infrastructure and expanding regional human capital throughout the country (e.g., the pre-decentralization Presidential Instructions scheme). Tax incentives and holidays have been promoted at the national and regional levels. However, their effectiveness for attracting foreign investment to Indonesia have been questioned (Wells and Allen 2001). International agencies such as the World Bank are also undertaking transport improvement projects to bridge the development gap in the lagging eastern provinces of Indonesia. For example, the World 
Bank's 'Indonesia Region Transport Project (EIRTP)' will cover 15 provinces in Indonesia's eastern islands -- namely Kalimantan, Sulawesi, Bali, Nusa Tenggara, Maluku, and Irian Jaya, in an attempt to improve access to employment opportunities, health, education, and other social services and facilities. Government officials have recently argued that infrastructure investments and tax holidays were needed as a means of accelerating growth in Eastern Indonesia. ${ }^{17}$

The methodology applied in this paper underscores the need for a better understanding of location determinants for manufacturing firms, as well as the need to see the outcome of potential policy interventions in a new economic geography context. Our estimates of location determinants suggests that agglomeration economies are important in explaining the distribution of manufacturing activity, and neglecting the role of these factors may have serious implications for the success of regional development initiatives aimed at creating industrial bases in lagging regions.

Our simulations suggest in the presence of agglomeration economies, increases in infrastructure endowment for lagging regions may have only limited payoffs in terms of attracting firms from other more established "leading" regions, particularly in main stream sectors that have already concentrated in other leading regions. Work on industrial location in Brazil, for example, underscores that lagging regions may need to focus on industries building on existing location endowments (including natural resources), rather than attempting to compete for sectors that have already agglomerated in leading regions (Lall, et al. 2004a). Given that standard manufacturing that has already concentrated in large agglomerations is unlikely to move to peripheral locations, it is very important to think of alternate strategies that are feasible for low density and remote areas.

Indonesia's recent decentralization has placed increased emphasis on local political economy factors (taxation, licensing $\&$ bureaucratic red tape, and the provision of public services for attracting new firms). Our analysis was not able to establish a strong role of these types of factors in the location decisions of formal manufacturing

\footnotetext{
${ }^{17}$ Former president Abdurrahman Wahid established the Office of the State Minister for Development Acceleration of Eastern Indonesia for the acceleration of development in Eastern Indonesia.
} 
firms. Part of this is because several important components of local regulations are not observed in the available data. Recent evidence from an ADB/WB Investment Climate Survey suggests that firms perceive these factors to be important. Coverage limitations for this data, however, do not allow us to weigh the importance of these factors against other location factors identified in this paper. Much like our findings for infrastructure, lagging regions may not be able to overcome the costs imposed by location specific characteristics even though they may be leaders in reforming their investment climates. At the margin, leading or intermediate regions may therefore stand most to gain from local policy interventions, although lagging regions may face more of an uphill struggle to implement these interventions. Future work will need to demonstrate the link between firm location decisions and local government behavior.

\section{References}

Arrow, K. J. (1962). The Economic Implications of Learning by Doing. Review of Economic Studies, 29, 155-173.

Azzoni, C. R. (2001). Economic growth and regional income inequality in Brazil. Annals of Regional Science, 35, 1, 133-152.

Azzoni, C. R., N. Menezes-Filho, T. A. de Menezes and R. Silveira-Neto. (2003). "Geography and Income Convergence Among Brazilian States." Mimeo. Department of Economics, Universidade de São Paulo, Brazil

Bayer, P. and C. Timmins (2003). "Estimating equilibrium models of sorting across locations." Mimeo, Yale University.

Besley, T. and R. Burgess (2004). Can Labor Regulation Hinder Economic Performance? Evidence from India," The Quarterly Journal of Economics, 119(1), 91-134, February. BPS (1997), Indonesia Statistical Yearbook 1997, Table 8.1.4, Jakarta, Badan Pusat Stastik. BPS (2001). Potensial Desa (PODES), Village Potential Statistics. Jakarta, Badan Pusat Stastik.

Burgess R. and A. J. Venables (2004). Towards a microeconomics of growth. Policy Research Working Paper 3257. World Bank.

Cikurel, D, (2002), 'Why Mexico's regional convergence broke down', mimeo, University of California, San Diego and at, http://www.wider.unu.edu/conference/conference-20025/conference2002-5.htm. 
Deichmann, U., M. Fay, J. Koo, and S. V. Lall (2004). "Economic Structure, Productivity and Infrastructure Quality in Southern Mexico.” Annals of Regional Science, 38, 1-25, 2004.

Ellison, G. and E. Glaeser (1997). "Geographic Concentration in US Manufacturing Industries: A Dartboard Approach. Journal of Political Economy, 105(5):889-927.

Ellison, G. and E. Glaeser (1999). The Geographic Concentration of Industry: Does Natural Advantage Explain Agglomeration? American Economic Review, Papers and Proceedings, 89(2), $311\{316$.

ESRI (1993). Digital Chart of the World for use with ARC/INFO: data dictionary. ESRI, Redlands, California.

Fan, C.C. and E. Casetti (1994). The Spatial and Temporal Dynamics of U.S. Regional Income Inequality. The Annals of Regional Science, 28(2), 177-196.

Fujita, M, and J. Thisse (2001). Economics of agglomeration. Cambridge University Press.

Fujita, M., and P. Krugman (1995). When is the Economy Monocentric? Von Thunen and Chamberlain United. Regional Science and Urban Economics, 25(4), 505-528.

Fujita, M, P. Krugman, and A.J. Venables (1999). The Spatial Economy: Cities, Regions, and International Trade, MIT Press.

Fujita, M. and D. Hu (2001). Regional disparity in China 1985-1994: The effects of globalization and economic liberalization. Annals of Regional Science, 35:3-37.

Henderson, J.V., A. Kuncoro, and D. Nasution (1996). The Dynamics of Jabotabek Development. Bulletin of Indonesian Economic Studies, 32:1, 71-95.

Henderson, J.V., T. Lee, and Y.J. Lee (2001). Scale Externalities in Korea. Journal of Urban Economics, 49, 479-504.

Henderson, J.V. (2003). The Urbanization Process and Economic Growth: The So-What Question, Journal of Economic Growth, 8, 47-71.

Hill, H. (1990). Indonesia's Industrial Transformation, Part I. Bulletin of Indonesian Economic Studies, 26:2, 79-120.

Jian, T., J. Sachs and A. Warner (1996). Trends in regional inequality in China. China Economic Review, 7, 1, Spring, 1-22.

JRC (2003), Global Land Cover 2000 database. European Commission, Joint Research Centre, Ispra (http://www.gvm.jrc.it/glc2000).

Krugman, P. (1991a). Geography and Trade. Cambridge, Mass.: MIT Press.

Krugman, P. (1991b). Increasing returns and economic geography. Journal of Political Economy, 99, 483-499. 
Lall S.V., R. Funderburg, and T. Yepes. (2004a). Location, Concentration, and Performance of Economic Activity in Brazil. Policy Research Working Paper 3268. World Bank.

Lall, S.V., Z. Shalizi and U. Deichmann. (2004b). "Agglomeration Economies and Productivity in Indian Industry." Journal of Development Economics, 73, 2, 643-673, 2004.

Lall, S.V. and S. Chakravorty (forthcoming). "Industrial Location and Spatial Inequality: Theory and Evidence from India". Forthcoming, Review of Development Economics.

Rey, S. J. and Montouri, B. D. (1999). U.S. regional income convergence: A spatial econometric perspective. Regional Studies, 33:143-156.

Marshall, A. (1890). Principles of Economics. London: Macmillan.

McCann, P. (1998). The economics of industrial location: a logistics-costs approach. Series on Advances in Spatial Science. Springer, Heidelberg.

Murphy, K.M., A. Shleifer, R. Vishny (1989). Industrialization and the Big Push. Journal of Political Economy, Vol. 97, 1003-1026

Romer, P. M ( 1986). Increasing Returns and Long-run Growth, Journal of Political Economy, 94 (5), 1002-37, October.

Rosenthal, S. and W. C. Strange (2003), Evidence on the nature and sources of agglomeration economies, in V. Henderson and J. Thisse, Handbook of Urban and Regional Economics Vol. 4.

Timmins, C. (forthcoming), Estimable equilibrium models of locational sorting and their role in development economics, Journal of Economic Geography.

Venables, A. J. (1996). Equilibrium locations of vertically linked industries. International Economic Review, 49, 341-359.

Venables, A. J. (2003), Spatial disparities in developing countries: cities, regions and international trade, London School of Economics, London (http://econ.1se.ac.uk/staff/ajv/).

Wen, M. (2001). Relocation and Agglomeration of Chinese Industry. http://rspas.anu.edu.au/economics/publish/papers/wp2001/2001$\underline{07 \% 20 \mathrm{MeiWenWP2v} \text {.pdf }}$

Wells, L. T. and N. J. Allen. (2001). "Tax Holidays to Attract FDI: Lessons from Two "Experiments"." 39. Harvard Business School: Cambridge, MA, mimeo (forthcoming FIAS, IFC/World Bank), (February 9th).

Zhang, X. and Kanbur, R. (2001). What difference do polarisation measures make? An application to China. Journal of Development Studies. 37: 85-98. 
Table 1: Agglomeration economies

\begin{tabular}{|c|c|c|l|}
\hline $\begin{array}{c}\text { Localization } \\
\text { economies / } \\
\text { Own-industry } \\
\text { concentration }\end{array}$ & $\begin{array}{c}\text { Linkages } \\
\text { between } \\
\text { complementary } \\
\text { sectors }\end{array}$ & $\begin{array}{c}\text { Urbanization } \\
\text { economies / } \\
\text { Diversity }\end{array}$ & Example \\
\hline High & Low & Low & Cluster of same-sector firms \\
\hline Low & High & Low & Cluster of interdependent firms \\
\hline Low & High & High & Diverse set of firms with few complementarities \\
\hline High & Low & High & $\begin{array}{l}\text { Firmster of same-sector firms with many } \\
\text { interdependent production processes }\end{array}$ \\
\hline High & High & High & Diversented set of interdependent sector firms \\
\hline Low & High & High & $\begin{array}{l}\text { Diverse set of interdependent firms with some } \\
\text { represented prominently }\end{array}$ \\
\hline High & & \\
\hline
\end{tabular}


Table 2: Sectoral composition of the Survey of Industry 2001

\begin{tabular}{clrr}
\hline ISIC & Sector & $\begin{array}{r}\text { Number } \\
\text { of firms }\end{array}$ & $\begin{array}{c}\text { Number } \\
\text { of } \\
\text { employees }\end{array}$ \\
\hline 15 & Food products and beverages & 4,544 & 581,720 \\
16 & Tobacco & 808 & 258,747 \\
17 & Textiles & 1,897 & 595,082 \\
18 & Wearing apparel & 2,123 & 497,816 \\
19 & Tanning and dressing of leather & 561 & 279,497 \\
20 & Wood and products of wood except furniture and plaiting materials & 1,667 & 401,435 \\
21 & Paper and paper products & 383 & 115,378 \\
22 & Publishing, printing and reproduction of recorded media & 535 & 49,091 \\
24 & Chemicals and chemical products & 1,071 & 221,672 \\
25 & Rubber and plastics products & 1,392 & 336,860 \\
26 & Other non-metallic mineral products & 1,655 & 174,639 \\
27 & Basic metals & 236 & 61,019 \\
28 & Fabricated metal products, except machinery and equipment & 904 & 117,249 \\
29 & Machinery and equipment n.e.c & 527 & 124,198 \\
$30 \& 33$ & Office, accounting, and computing machinery \& Medical, precision & 78 & 18,920 \\
& and optical instruments, watches and clock & & \\
$31 \& 32$ & Electrical and Electronics \& Radio, television and communication & 376 & 138,185 \\
& equipment and apparatus & & \\
34 & Motor vehicles, trailers and semi-trailers & 216 & 49,483 \\
35 & Other transport equipment & 354 & 67,032 \\
36 & Furniture and manufacturing n.e.c & 1,910 & 280,912 \\
& Total & 21,237 & $4,368,935$ \\
\hline
\end{tabular}


Table 3: Descriptive Statistics

\begin{tabular}{|c|c|c|c|c|}
\hline & & Source & Mean & Stdev \\
\hline \multirow[t]{19}{*}{$\sigma_{j, k}$} & $\begin{array}{l}\text { localization economies: share of } \\
\text { sector } k \text { firms in region } j\end{array}$ & $\begin{array}{l}\text { Survey of Industry } \\
2001\end{array}$ & & \\
\hline & Sectors & 15 & 0.003 & 0.005 \\
\hline & & 16 & 0.003 & 0.014 \\
\hline & & 17 & 0.003 & 0.015 \\
\hline & & 18 & 0.003 & 0.012 \\
\hline & & 19 & 0.003 & 0.011 \\
\hline & & 20 & 0.003 & 0.005 \\
\hline & & 21 & 0.003 & 0.010 \\
\hline & & 22 & 0.003 & 0.011 \\
\hline & & 24 & 0.003 & 0.009 \\
\hline & & 25 & 0.003 & 0.009 \\
\hline & & 26 & 0.003 & 0.012 \\
\hline & & 27 & 0.003 & 0.011 \\
\hline & & 28 & 0.003 & 0.010 \\
\hline & & 29 & 0.003 & 0.014 \\
\hline & & $30 \& 33$ & 0.003 & 0.012 \\
\hline & & $31 \& 32$ & 0.003 & 0.014 \\
\hline & & 34 & 0.003 & 0.009 \\
\hline & & 36 & 0.003 & 0.010 \\
\hline$B S_{\mathrm{j}}$ & Complementary business services: & SUSENAS 2001 & .0121 & .0154 \\
\hline \multirow[t]{3}{*}{$M A_{j}$} & Market access: & & & \\
\hline & Road Density & $\mathrm{DCW} / \mathrm{BPS}$ & 749 & 1375 \\
\hline & $\begin{array}{l}\text { Travel time to nearest international } \\
\text { port }\end{array}$ & $\mathrm{DCW} / \mathrm{BPS}$ & 235447 & 423906 \\
\hline \multirow[t]{2}{*}{$W j$} & $\begin{array}{l}\text { Regional non-agricultural hourly } \\
\text { wage rate }\end{array}$ & SUSENAS (2001) & 4226 & 1907 \\
\hline & Industrial land availability & PODES (2001) & 1100 & 3996 \\
\hline$X_{j, k}$ & $\begin{array}{l}\text { Access to natural resources: percent } \\
\text { of area covered by cropland / forests } \\
\text { from satellite derived land cover } \\
\text { information }\end{array}$ & $\begin{array}{l}\text { Joint Research } \\
\text { Center (2003) }\end{array}$ & $\begin{array}{l}\text { Forest: } 35.05 \\
\text { Crop: } 50.70\end{array}$ & $\begin{array}{c}27.57 \\
23.89\end{array}$ \\
\hline$R_{j}$ & $\begin{array}{l}\text { Local Bureaucratic Costs of Doing } \\
\text { Business (dummy variable if district } \\
\text { has PERDA rejected in the review } \\
\text { process) }\end{array}$ & $\begin{array}{l}\text { Ministry of Home } \\
\text { Affairs }\end{array}$ & 0.13 & 0.34 \\
\hline
\end{tabular}


Table 4: Determinants of industry location decisions

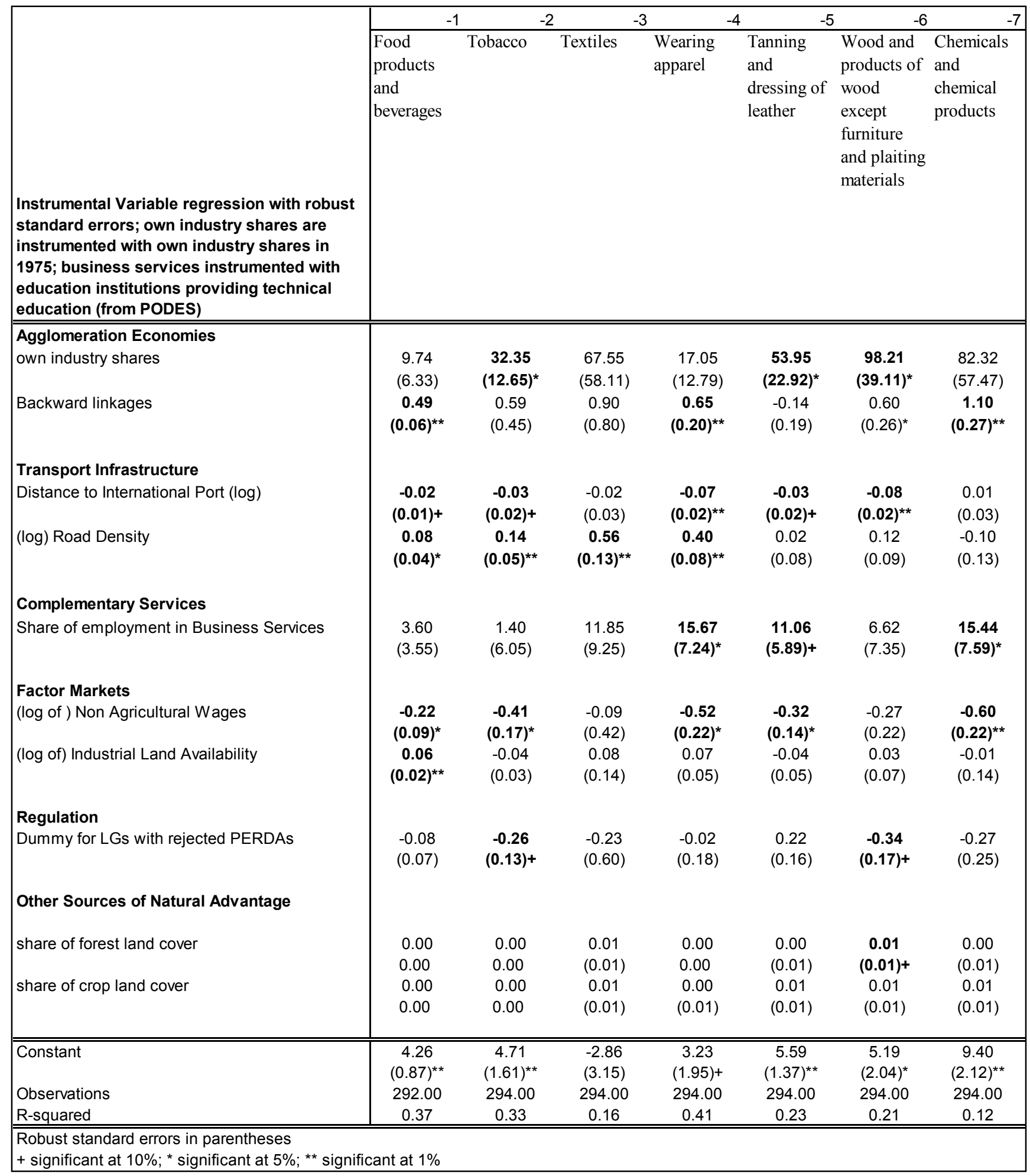


Table 4 (continued): Determinants of industry location decisions

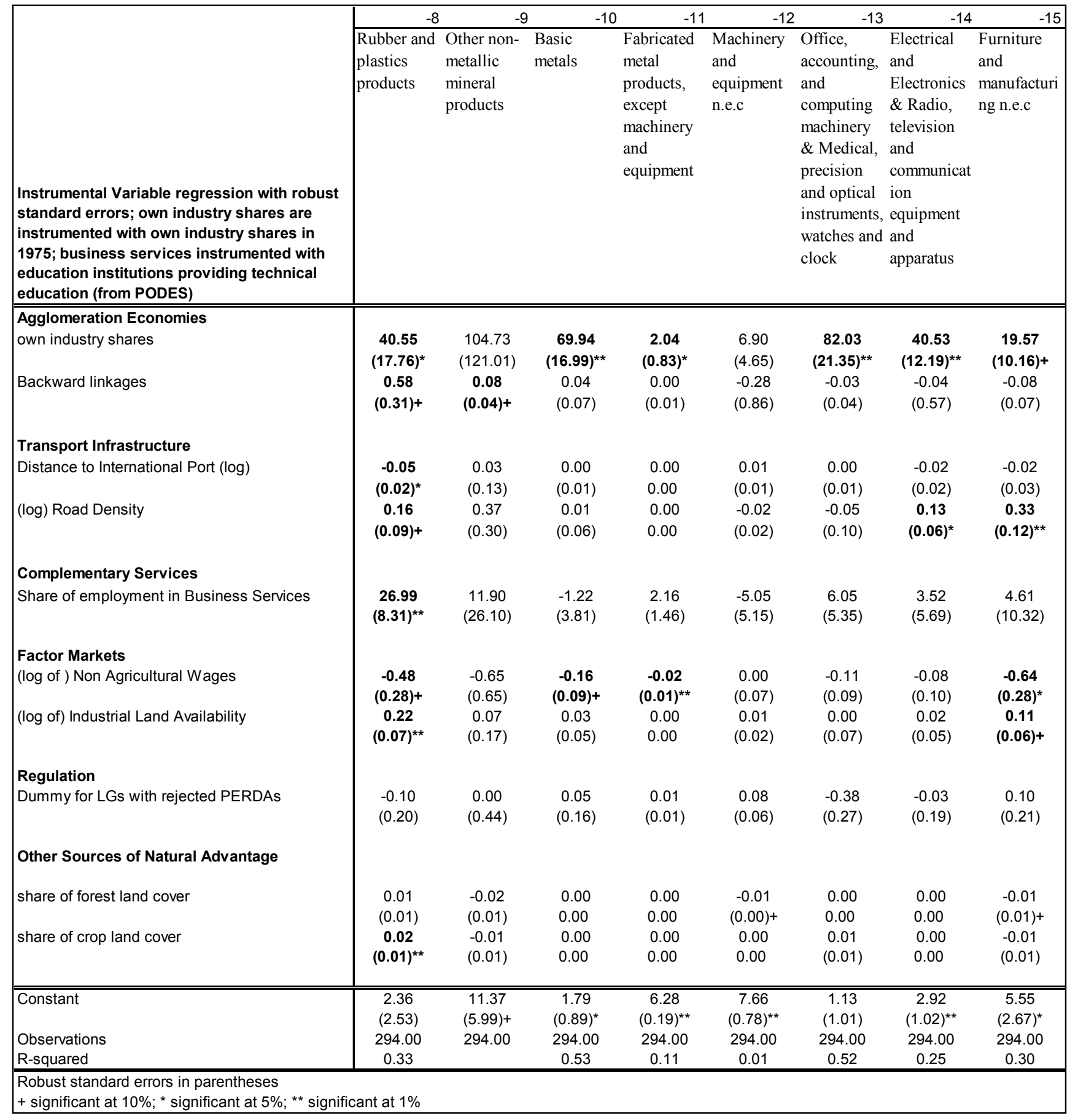


Table 5: Average Road Densities (km per one thousand $\mathbf{k m}^{2}$ )"

\begin{tabular}{lr}
\hline Region & Density \\
\hline Greater Jakarta Metro Area & 2400 \\
Greater Jakarta Metro Area (excluding DKI Jakarta) & 1102 \\
Municipalities in East Java & 2169 \\
All Districts in East Java & 974 \\
Municipalities in East Kalimantan and Sulawesi & 497 \\
All districts in East Kalimantan and South Sulawesi & 453 \\
\hline$*$ includes State, Province, Regency and Municipal roads (BPS 1997) &
\end{tabular}

Table 6: Simulations - Selecting Sectors by Transport Sensitivity and Agglomeration Economies

\begin{tabular}{lcll}
\hline Industry Sector & Transport Ranking & Transport Sensitivity & $\begin{array}{l}\text { Agglomeration } \\
\text { Effects }\end{array}$ \\
\hline \hline Garments & 2 & High & Low \\
Rubber and plastic & 5 & High & High \\
Wood Products & 8 & Moderate & High \\
Food and Beverages & 9 & Moderate & Low \\
Leather work & 10 & Low & Moderate \\
Office Computing & 14 & Low & Hlgh \\
\hline
\end{tabular}


Figure 1: Distribution of manufacturing employment in the footwear and food products sectors.

Each dot is randomly placed within a district and represents 500 employees. Source: Economic Census and Survey of Industry, 1996.
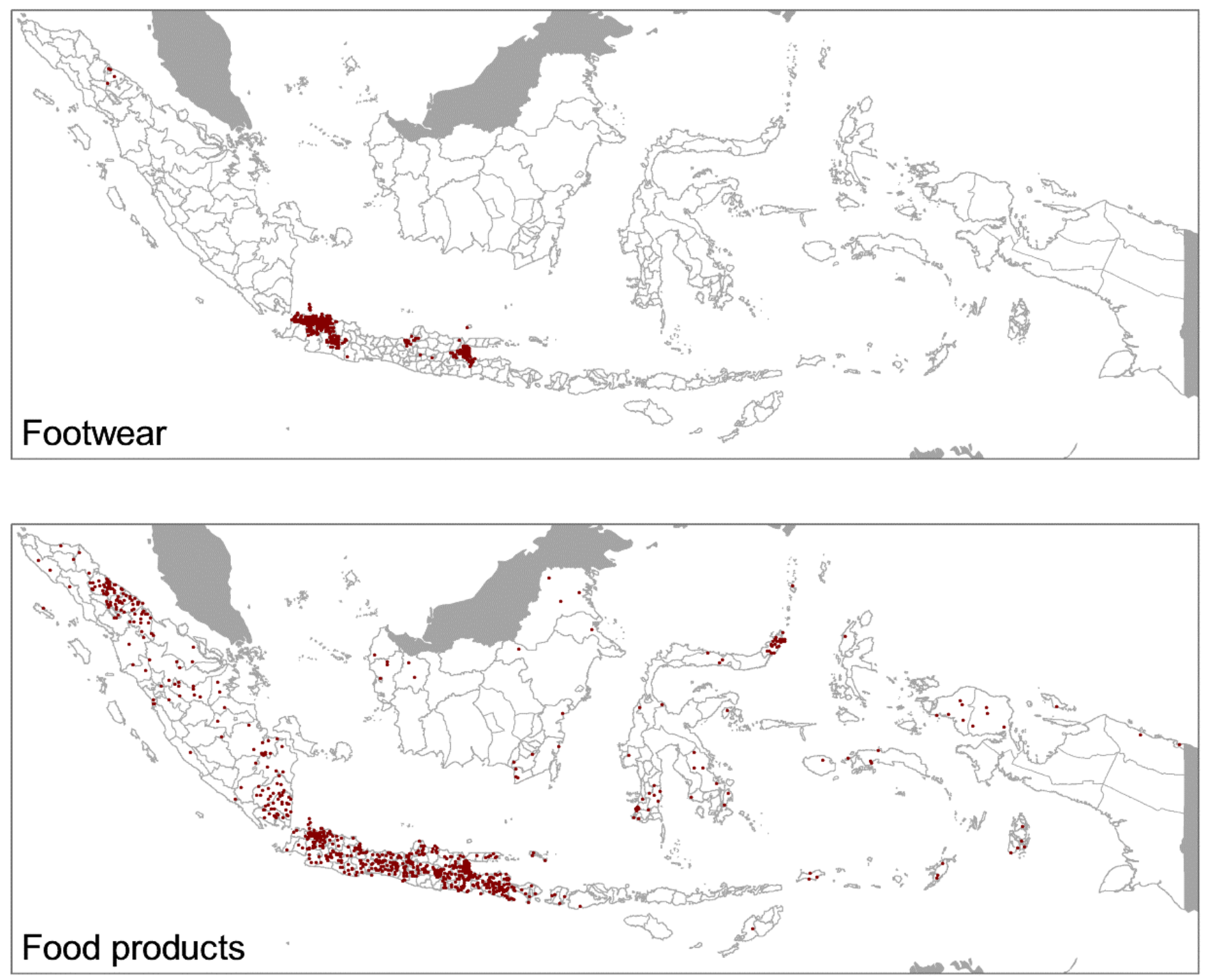
Figure 2: Distribution of manufacturing employment in the textile and garments sectors.

Each dot is randomly placed within a district and represents 500 employees. Source: Economic Census and Survey of Industry, 1996.
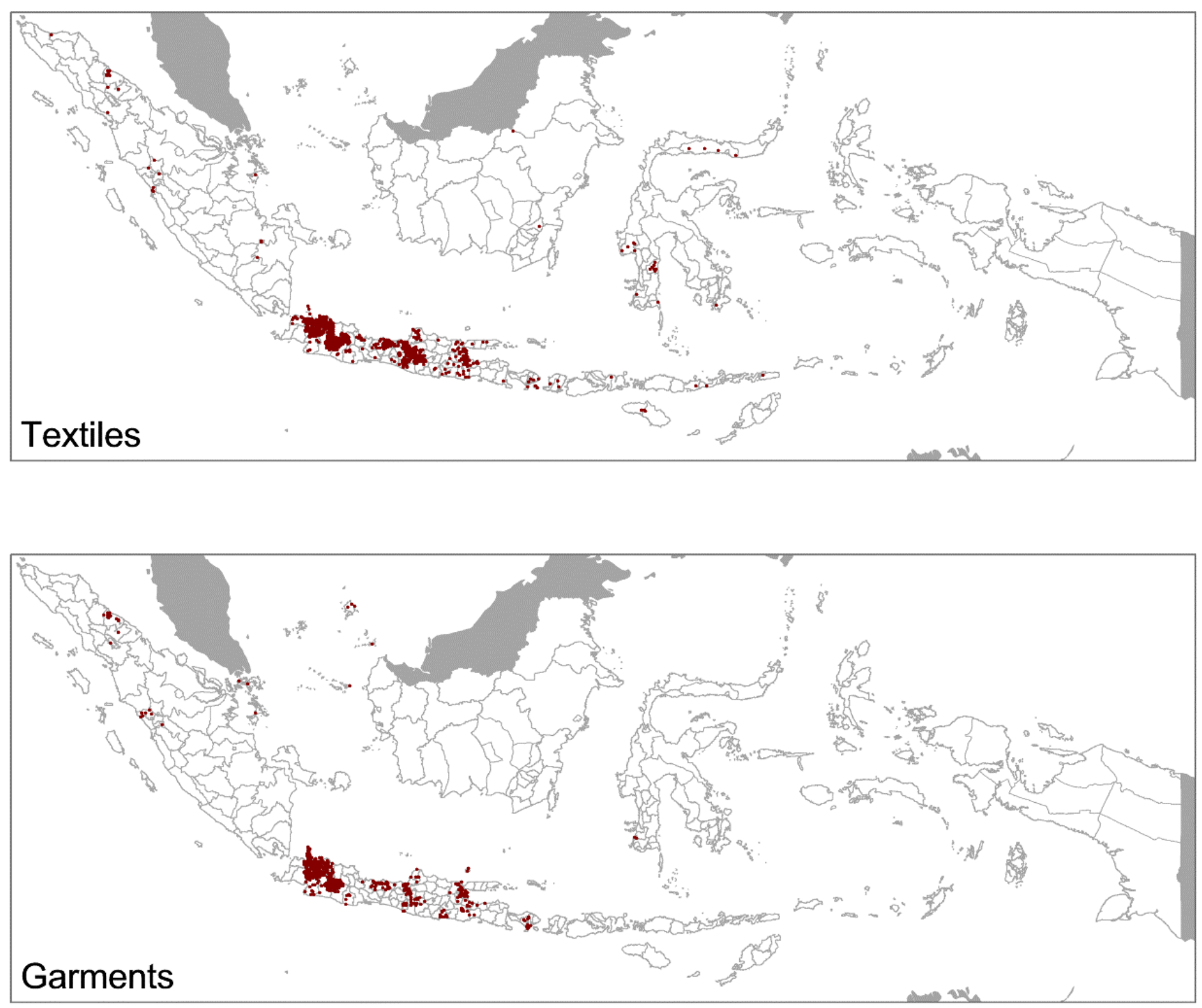
Figure 3: Distribution of manufacturing employment in the wood products sector and of total manufacturing employment.

Each dot is randomly placed within a district and represents 500 employees. Source: Economic Census and Survey of Industry, 1996.
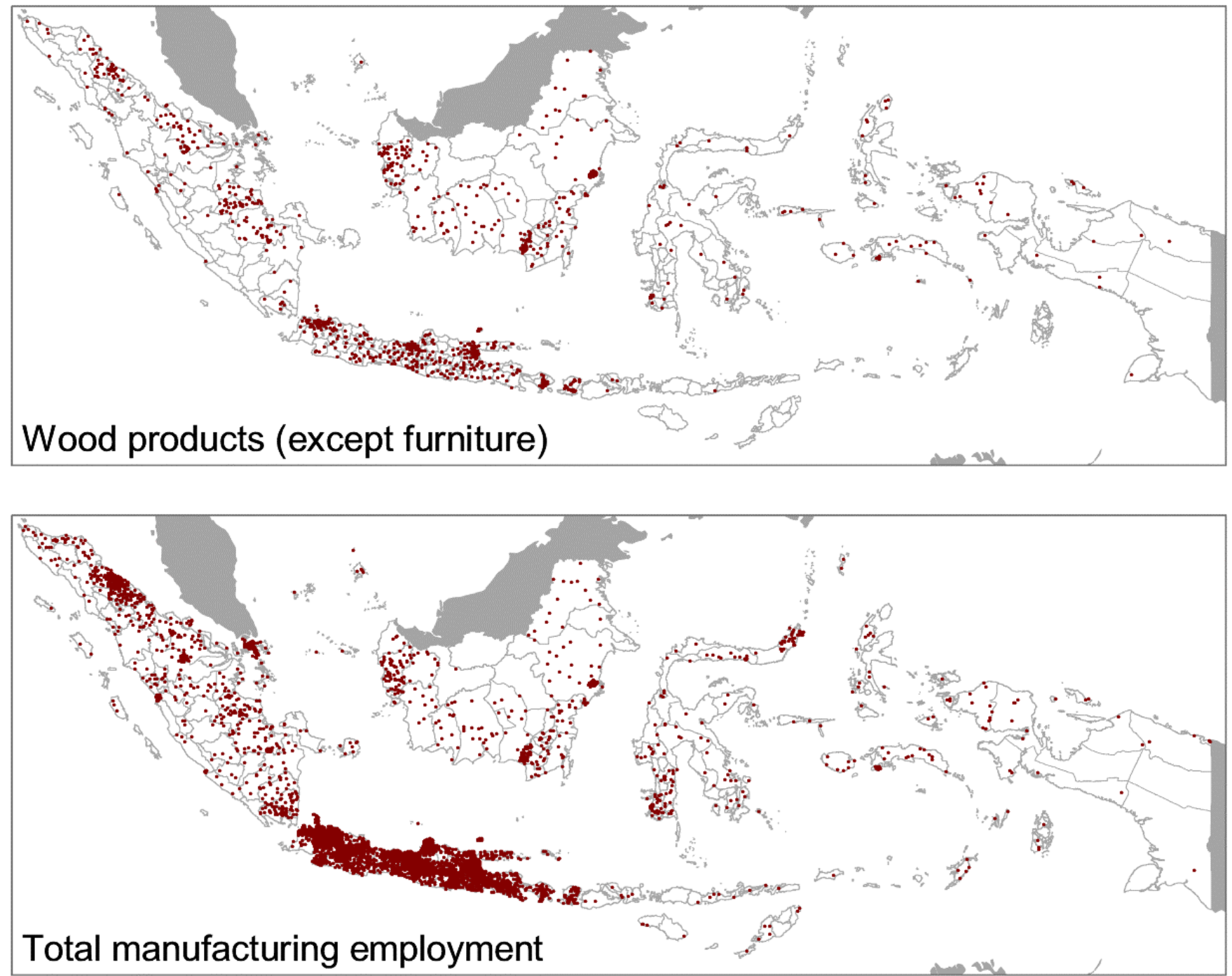
Figure 4: Non Agricultural Hourly Wages

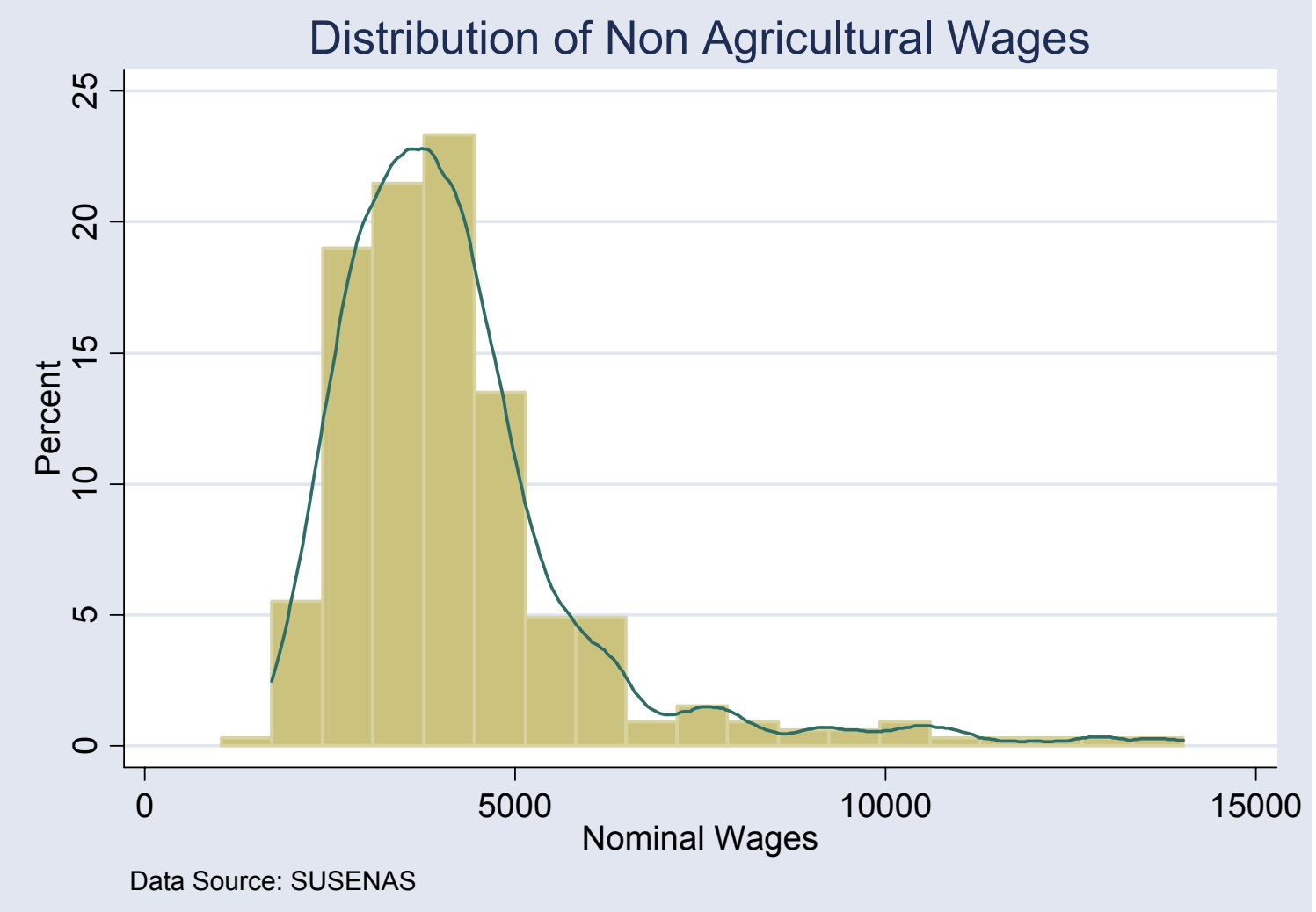


Figure 5a: High Transport Sensitivity Simulations
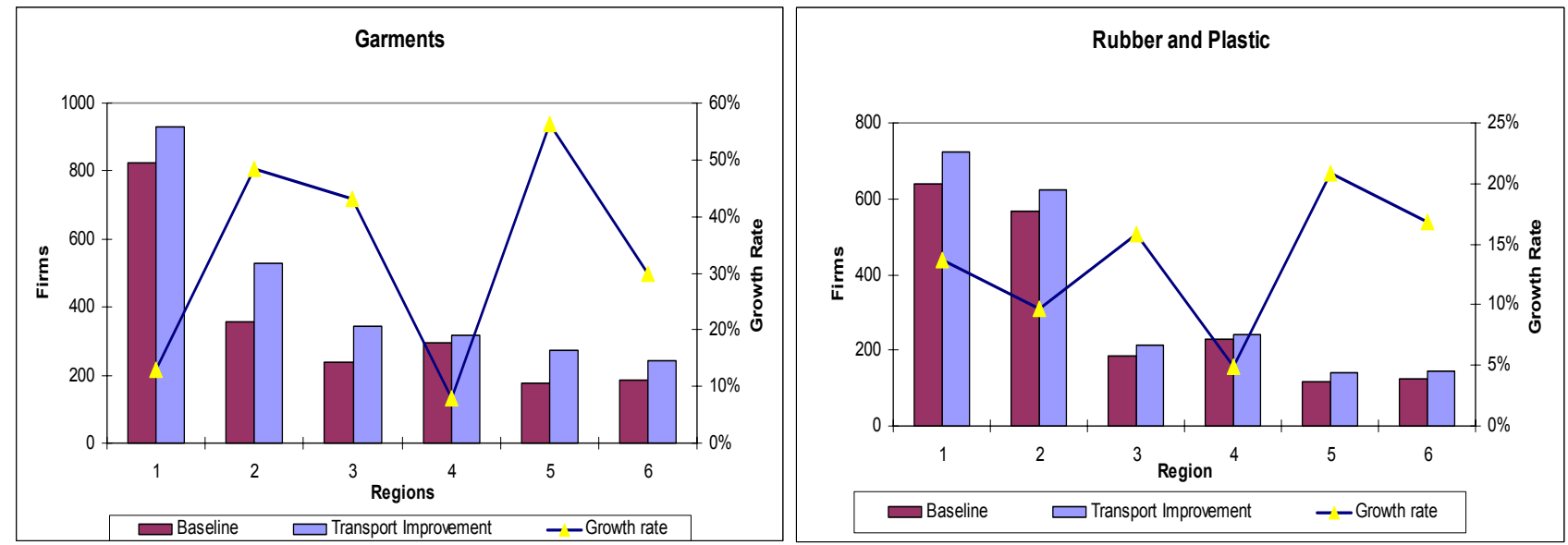

Figure 5b: Moderate Transport Sensitivity Simulations
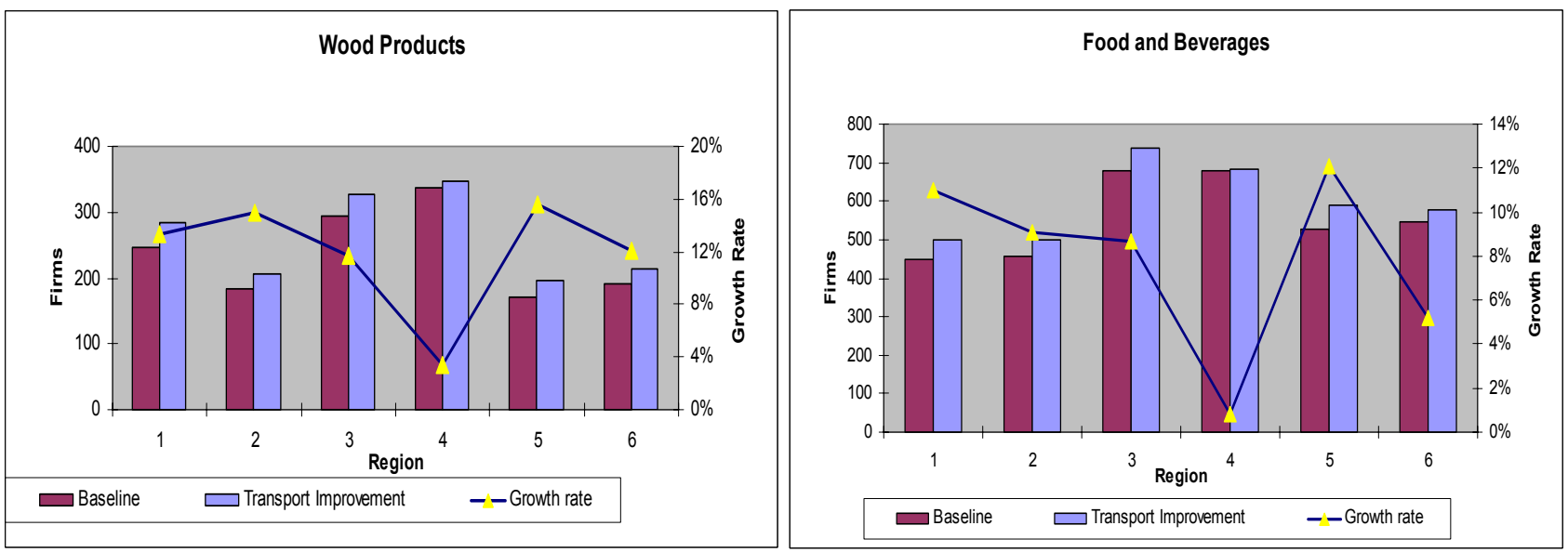

Figure 5b: Low Transport Sensitivity Simulations
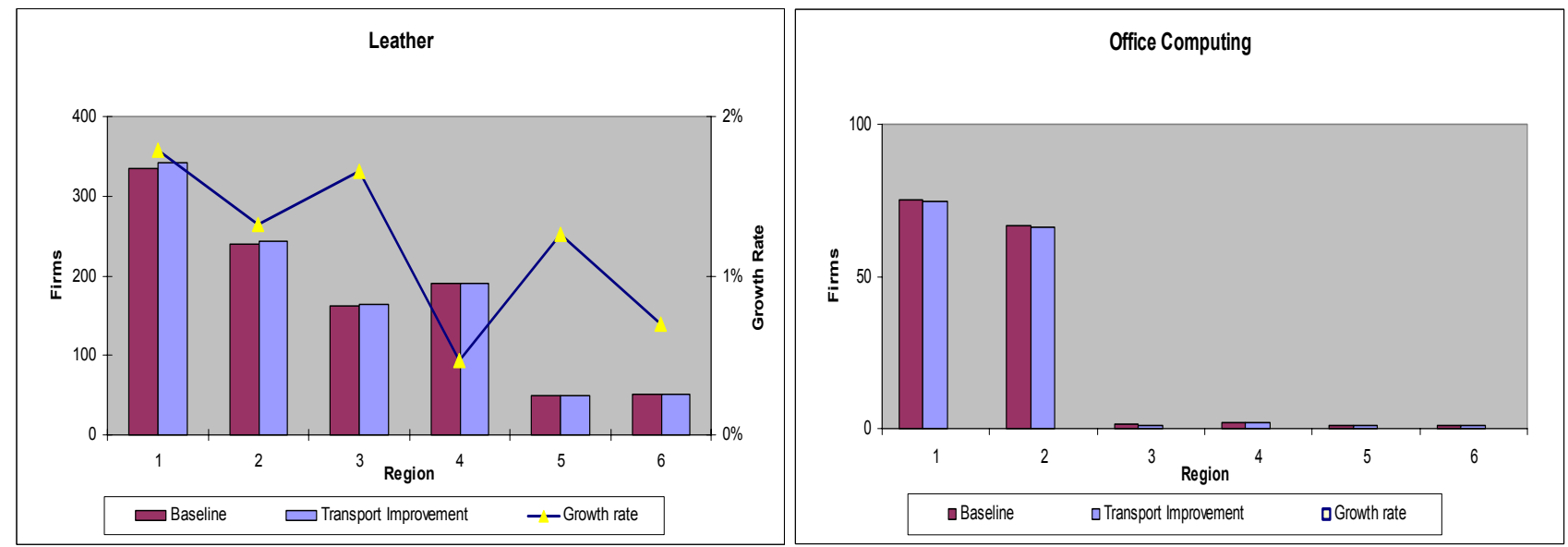